\begin{tabular}{llllllllll}
$\mathbf{I}$ & $\mathbf{N}$ & $\mathbf{M}$ & $\mathbf{E}$ & $\mathbf{M}$ & $\mathbf{O}$ & $\mathbf{R}$ & $\mathbf{I}$ & $\mathbf{A}$ & $\mathbf{M}$ \\
\hline
\end{tabular}

STUDIA POLONIJNE

T. 39. LUBLIN 2018

DOI: http://dx.doi.org/10.18290/sp.2018.16

WALDEMAR W. ŻUREK SDB

\title{
„BISKUP NA WALIZKACH”. DUSZPASTERZ EMIGRACJI POLSKIEJ, ARCYBISKUP SZCZEPAN WESOLY 1926-2018
}

W liturgiczne wspomnienie św. Augustyna, biskupa i doktora Kościoła, dnia 28 sierpnia 2018 roku zmarł w Rzymie długoletni i trzeci historycznie delegat prymasa Polski dla opieki nad emigracją i uchodźctwem polskim - ksiądz arcybiskup Szczepan Wesoły ${ }^{1}$. Pozostawił po sobie opinię gorącego patrioty i duchownego umiejącego właściwie docenić emigrację i uchodźctwo polskie. Odszedł do Pana w 92 roku życia, 62 roku kapłaństwa i 50 biskupstwa. Spoczął na wieczność w rodzinnych Katowicach. Z urodzenia - Ślązak. Z wyboru - Polak. Po powstaniach śląskich jego rodzice przenieśli się z Gliwic do Katowic, które po plebiscycie przypadły Niemcom. Wybrali Polskę. W roku świętowania 100-lecia jej niepodległości ten pasterz Kościoła otrzymał najwyższe odznaczenie w swojej Ojczyźnie - Order Orła Białego.

Dr hab. Waldemar W. Żurek SDB - Ośrodek Archiwów, Bibliotek i Muzeów Kościelnych KUL; e-mail: waldemarzurek@o2.pl

${ }^{1}$ Troskę pastoralną nad polską emigracją po drugiej wojnie światowej przejął jako zastępca protektora emigracji polskiej - kard. Augusta Hlonda, biskup polowy Wojska Polskiego Józef Feliks Gawlina. Przybył on do Włoch z armią generała Władysława Andersa i zamieszkał przy polskim kościele św. Stanisława Biskupa, którego został i był do 1964 roku rektorem. Po biskupie Gawlinie opiekę nad emigracją polską przejął biskup Stanisław Rubin, a w latach 1980-2003 funkcję delegata pełnił arcybiskup Szczepan Wesoły, administrator i opiekun ogromnego archiwum powstałego przy kościele Świętego Stanisława w Rzymie - Centralnego Ośrodka Duszpasterstwa Polaków za Granicą. W październiku 2011 roku biskupi polscy funkcję delegata Konferencji Episkopatu Polski ds. Duszpasterstwa Emigracji Polskiej i Przewodniczącego Komisji KEP ds. Polonii i Polaków za Granicą powierzyli biskupowi Wiesławowi Lechowiczowi z Tarnowa. J. BAKalarz, Emigracyjne duszpasterstwo, EK, t. IV, kol. 947-950. 
Ksiądz arcybiskup Wesoły urodził się 16 października 1926 roku w Katowicach. W ówczesnej katedrze pw. Świętych Apostołów Piotra i Pawła przyjął sakrament chrztu świętego. Urodził się w rodzinie, która po włączeniu Górnego Śląska do II Rzeczypospolitej zdecydowała zamieszkać w jej granicach. W śląskiej rodzinie, która nie zapomniała języka ojczystego i polskiego pacierza wychowywał się młody Szczepan. Był ministrantem.

W roku wybuchu drugiej wojny światowej ukończył szkołę podstawową. Szukając bezpiecznego miejsca, przed wybuchem wojny światowej wyjechał z rodziną z Katowic i zamieszkał w Jarosławiu. Następnie przez dwa lata pracował jako uczeń kupiecki w Sosnowcu. Po powrocie w 1941 roku do Katowic podjął pracę w hurtowni żelaza w hucie „Marta”. W październiku 1943 roku siedemnastoletni Szczepan został wywieziony na przymusowe roboty do Niemiec. Pracował przy budowie bunkrów w północnych Niemczech - w Cuxhaven, w kraju związkowym Dolna Saksonia. Wkrótce potem został przymusowo wcielony do armii niemieckiej ${ }^{2} \mathrm{i}$ wysłany na front zachodni do Cannes, w południowo-wschodniej Francji. W połowie sierpnia 1944 roku, w święto Wniebowzięcia Matki Bożej, jako Polak w niemieckim mundurze, w imię miłości do Polski, zaryzykował i przechodząc na stronę aliantów, stał się żołnierzem polskim. Zaszeregowany do służb łączności walczył z Niemcami na frontach w Algierii i we Włoszech jako radiotelegrafista. Po zakończeniu drugiej wojnie światowej z rzeszą żołnierzy polskich pozostał w Anglii. W tamtym czasie dokształcał się i równocześnie przez kilka lat pracował jako pracownik fizyczny w stalowni i w fabryce w Halifax. W tym czasie zarabiał na wyjazd do Rzymu, gdzie pragnął rozpocząć studia teologiczne i w ten sposób odpowiedzieć na głos powołania kapłańskiego. Dnia 3 maja 1950 roku wstąpił do kolegium jezuickiego „Campion House” pod Londynem, w którym uzupełnił wykształcenie z zakresu szkoły średniej ${ }^{3}$.

W latach 1951-1957, mieszkając w Papieskim Kolegium w Rzymie, studiował na Papieskim Uniwersytecie Gregoriańskim, gdzie uzyskał licencjat z teologii. Święcenia kapłańskie przyjął 28 października 1956 roku z rąk kard. Valerio Valerego, prefekta Kongregacji ds. Zakonów i został inkardynowany do diecezji katowickiej. W Rzymie spotykał biskupa polowego Wojska Polskiego i opiekuna emigracji polskiej - Józefa Gawlinę ${ }^{4}$, który wta-

2 „Niemcy brali wszystkich, bo przegrywali wojnę. Baliśmy się strasznie, a dla matki to była ostateczna tragedia. Jak wzięli brata, mogłem teoretycznie uciec do Generalnej Guberni, ale mama zostałaby z naszym najmłodszym bratem, wówczas trzynastoletnim. W najlepszym wypadku zabraliby jej zasiłek, w najgorszym wysłali do Auschwitz. Moja ucieczka przed niemieckim wojskiem nie wchodziła więc w grę". Nie żyje abp Szczepan Wesoty, https://katowice.gosc.pl/doc/4990304. Nie-zyje-abp-Szczepan-Wesoly [dostęp: 18.11.2018].

3 Zmarl abp Szczepan Wesoly, List abpa Wiktora Skworca, metropolity katowickiego, po śmierci Szczepana Wesołego, Katowice 28 sierpnia 2018 roku, https://episkopat.pl/nie-zyje-abp-szczepan-wesoly/ [dostęp: 18.11.2018].

${ }^{4}$ Od 1945 roku biskup Gawlina był zastępcą protektora emigracji polskiej kard. Augusta Hlonda. To on był założycielem drukarni i wydawnictwa biskupa polowego, przekształconego po wojnie w katolicki ośrodek wydawniczy Veritas w Londynie, oraz założycielem i redaktorem „Duszpasterza Polskiego za Granicą”. Biskup Gawlina współtworzył polskie misje katolickie w Europie, Afryce, Ameryce Południowej. Brał udział w Soborze Watykańskim II. Powołał do życia i przewodniczył 
jemniczał kleryka, a następnie kapłana Wesołego w formy duszpasterstwa Polaków na uchodźctwie.

Po październikowej odwilży, w 1957 roku neoprezbiter Wesoły odwiedził Polskę. Pragnął zobaczyć się z najbliższymi - rodziną, odprawił Mszę świętą prymicyjną i spotkał się z biskupem wygnańcem Stanisławem Adamskim ${ }^{5}$. Wkrótce powrócił do Rzymu, by podjąć, na życzenie arcybiskupa Gawliny, duszpasterstwo emigrantów polskich przebywających we Włoszech. Tę posługę pastoralną spełniał do 1962 roku oraz angażował się w przygotowanie wydawnictw związanych z Millenium Chrztu Polski. Od grudnia 1959 roku kontynuował naukę w Papieskim Instytucie Pastoralnym przy Uniwersytecie Laterańskim. W latach 1961-1962 studiował w Akademii św. Alfonsa i w dominikańskim Uniwersytecie „Pro Deo” w Rzymie. Opatrznościowa była jego obecność w Wiecznym Mieście w czasie Soboru Watykańskiego II, kiedy przez trzy lata (1962-1965) kierował Sekcją Słowiańską Biura Prasowego Sekretariatu Soboru. Redagował biuletyn informacyjny dla dziennikarzy z Europy Wschodniej, w czym wydatnie pomogła mu znajomość języków obcych. Po zakończeniu soboru i obronie w 1967 roku doktoratu z teologii na Uniwersytecie Laterańskim, objął kierownictwo Centralnego Ośrodka Duszpasterstwa Emigracyjnego w Rzymie ${ }^{6}$.

W grudniu 1968 roku został mianowany przez papieża Pawła VI biskupem tytularnym Dragona i sufraganem gnieźnieńskim. Sakrę biskupią przyjął 11 grudnia 1968 roku w prywatnej kaplicy prymasa Stefana Wyszyńskiego. Hasłem jego posługi biskupiej były słowa: Laetus serviam - będę służył z radością. Został oddelegowany do pomocy

Światowemu Komitetowi Obchodów Tysiąclecia Chrześcijaństwa w Polsce. P. TARAs, Gawlina Józef Feliks, EK, t. V, kol. 897-898.

${ }^{5}$ Biskup Stanisław AdAMsKi (1875-1967) - działacz społeczny i polityczny, biskup katowicki. Urodził się w Zielonej Górze. Studia seminaryjne ukończył w seminarium duchownym w Poznaniu i Gnieźnie. Święcenia kapłańskie przyjął 12 listopada 1899 roku. Pracował w duszpasterstwie w Gnieźnie i Poznaniu. Zaangażowany był w pracę w stowarzyszeniach katolickich, robotniczych, spółdzielczych. W powstaniu wielkopolskim został naczelnikiem rządu dzielnicowego. Brał czynny udział w tworzeniu Wojska Polskiego. W 1930 roku został dyrektorem Naczelnego Instytutu Akcji Katolickiej. Dnia 30 listopada tego roku został biskupem w Katowicach. W listach pasterskich poruszał problemy społeczne, religijne i narodowe. Zorganizował Katolicką Agencję Prasową. W czasie drugiej wojny światowej został wysiedlony z Katowic. Przebywał w latach 1941-1945 w Częstochowie i Warszawie. W styczniu 1945 roku powrócił do diecezji i organizował pracę duszpasterską. W odwecie za petycję w sprawie powrotu nauki religii do szkoły 7 listopada 1952 roku wraz z biskupem Herbertem Bednorzem i biskupem Bieńkiem został wydalony z diecezji. Ostatecznie przebywał u sióstr urszulanek w Lipnicy koło Szamotuł. Dnia 15 maja 1956 roku prokuratura generalna wydała orzeczenie rehabilitacji trzech wysiedlonych biskupów katowickich. Schorowany biskup Adamski stopniowo przekazywał agendy diecezjalne swemu koadiutorowi biskupowi Bednorzowi. J. Myszor, Adamski Stanisław, w: Stownik biograficzny katolickiego duchowieństwa Śląskiego XIX i XX wieku, red. M. Pater, Katowice 1996, s. 6-11.

${ }^{6}$ Deo et Patriae. Wyjątki z homilii abp. Wiktora Skowrca na pogrzebie abp. Szczepana Wesołego w: „Przegląd Katolicki”. Polish Catholic Review-Registered by Australia 2018, nr 11(548), s. 3; Wesoły Szczepan, w: G. PolaK, Kto jest kim w Kościele?, Warszawa 1996, s. 400. 
biskupowi Władysławowi Rubinowi ${ }^{7}$ - delegatowi Prymasa Polski ds. duszpasterstwa emigracyjnego ${ }^{8}$.

W 1980 roku przejął po biskupie Rubinie funkcję delegata prymasa Polski nad duszpasterstwem emigracji i uchodźctwem polskim w świecie, którą pełnił do przejścia na emeryturę w kwietniu 2003 roku. Rezydował w Rzymie, skąd podejmował posługę pastoralną dla polskich środowisk na świecie - służąc „starej” i „nowej” emigracji. W tym roku rozpoczęła się najwspanialsza karta jego życia i posługi biskupa emigracji. Wybiegając w przyszłość jako opiekun i pasterz polskiej emigracji, w liście do Rodaków z 26 sierpnia 1980 roku pisal, że ,polskie duszpasterstwo potrzebne jest nie tylko z powodu nieznajomości języka kraju zamieszkania, ale ze względu na odrębność psychiczną płynącą z oparcia o polską kulturę. Z niej bowiem pochodzą formy kultu, nasza pobożność i polska religijność" św. Stanisława Biskupa i Męczennika przy Via delle Botteghe Oscure w Rzymie ${ }^{10}$ oraz funkcję przewodniczącego Rady Administracyjnej Fundacji Jana Pawła $\mathrm{II}^{11}$ i redaktora

${ }^{7}$ Kardynał Władysław Rubin (1917-1990). Urodził się na Kresach Wschodnich Polski. Teologię studiował od 1935 roku na Uniwersytecie Jana Kazimierza we Lwowie. Walczył w czasie kampanii wrześniowej 1939 roku. Aresztowany przez Sowietów i wywieziony w głąb ZSRR, po odzyskaniu wolności wstąpił do armii gen. Władysława Andersa. Od 1943 roku kontynuował studia teologiczne. W 1946 roku przyjął święcenia kapłańskie i podjął pracę duszpasterską w Bejrucie. Po studiach na Gregorianum (1949-1953) podjął pracę w Centralnym Ośrodku Emigracji Polskiej w Rzymie. Był rektorem Polskiego Kolegium w Rzymie, rektorem kościoła polskiego i Hospicjum św. Stanisława Biskupa oraz delegatem prymasa Polski do opieki nad duszpasterstwem polonijnym. W 1979 roku został kreowany kardynałem. Pełnił wysokie urzędy w kongregacjach Stolicy Apostolskiej. J. SzYMAŃSKI, Rubin Władysław, EK, t. XVII, kol. 509-510.

8 Życiorys abp Szczepan Wesoly, http://www.kul.pl/zyciorys-abp-szczepan-wesoly,art_12012. html [dostęp: 20.10.2018].

${ }^{9}$ Nie żyje abp Szczepan Wesoly, https://katowice.gosc.p1/doc/4990304.Nie-zyje-abp-Szczepan-Wesoly [dostęp: 18.10.2018].

${ }^{10}$ Kościół i Hospicjum św. Stanisława Biskupa i Męczennika - jest najstarszym i najcenniejszym polskim zabytkiem poza krajem. To jedyny i prawdziwy kościół polski w Rzymie. Jego inicjatorem i fundatorem był kard. Stanisław Hozjusz, wielki Penitencjarz w Rzymie podczas Roku Jubileuszowego 1575. Od 1578 roku kościół św. Stanisława jest polską parafią i najbardziej znanym miejscem spotkań katolickiej Polonii. J. KopIEc, Hospicjum i kościót św. Stanisława w Rzymie - dom i miejsce postugi arcybiskupa Szczepana Wesołego, w: W nieustającej trosce o polska diaspore, red. R. Nir, M. Szczerbiński, K. Wasilewski, Gorzów Wielkopolski 2012, s. 189-199.

${ }^{11}$ Fundacja Jana Pawła II - to organizacja kościelna ustanowiona dekretem papieskim z 16 października 1981 roku, która popiera i realizuje inicjatywy o charakterze edukacyjnym, naukowym, kulturalnym, religijnym i charytatywnym, związane z pontyfikatem Ojca Świętego Jana Pawła II. Ma swoją siedzibę w Watykanie. Działalność Fundacji obejmuje m.in. program stypendialny dla studentów z Europy Wschodniej na Katolickim Uniwersytecie Lubelskim i Uniwersytecie Papieskim Jana Pawła II w Krakowie. Prowadzi Ośrodek Dokumentacji i Studium Pontyfikatu Jana Pawła II, który zajmuje się zabezpieczeniem dokumentów dotyczących pontyfikatu Jana Pawła II i dba o przekazanie jego dziedzictwa przyszłym pokoleniom. Prowadzi Dom Fundacji Jana Pawła II w Rzymie, który służy pielgrzymom z całego świata. Dzieła te są realizowane dzięki systematycznej pomocy finansowej i wsparciu przyjaciół $z$ całego świata. 
naczelnego „Duszpasterza Polskiego za Granicą”, Dnia 8 kwietnia 2003 roku papież Jan Paweł II przyjął jego rezygnację z pełnionych urzędów i przeniósł na emeryturę ${ }^{13}$.

Zebrane w ciągu lat zasługi Biskupa spowodowały, że otrzymał wyróżnienia kościelne, państwowe, uczelniane i polonijne. Papież Jan Paweł II obdarzył go dnia 7 lutego 1994 roku godnością arcybiskupa ad personem. Postanowieniem prezydenta RP Andrzeja Dudy został odznaczony 5 maja 2018 roku najwyższym orderem państwowym w Polsce - Orderem Orła Białego ${ }^{14}$. Wcześniej postanowieniem prezydenta Lecha Kaczyńskiego z 26 listopada 2007 roku został odznaczony Krzyżem Wielkim Orderu Odrodzenia Polski ${ }^{15}$. Zarządzeniem prezydenta Ryszarda Kaczorowskiego z 11 listopada 1990 roku został odznaczony Wstęgą tego samego orderu. Katolicki Uniwersytet Lubelski nadał mu pierwszy doktorat honoris causa. Herb Uczelni i słowa Deo et Patriae - to także synteza życia i pracy arcybiskupa Wesołego, życia dla Boga i Ojczyzny. Uniwersytet Śląski w Katowicach nadał mu również doktorat honoris causa w 2015 roku. Tu na Śląsku, w swojej małej ojczyźnie - w Katowicach przyznano mu w 1996 roku Honorowe Obywatelstwo rodzinnego miasta. Wyróżniony także został nagrodami honorowymi. W 2003 roku został wyróżniony statuetką Fidelis Poloniae za umacnianie związków z ojczyzną. W 2006 roku otrzymał Wawrzyn Polonijny Stowarzyszenia „Wspólnota Polska”, rok później nagrodę Lux et Silesia ${ }^{16}$

12 „Duszpasterz Polski za Granicą” - dwumiesięcznik wydawany od 1949 roku w Rzymie przez Centralny Ośrodek Duszpasterstwa Emigracji Polskiej. Do 1965 roku ukazywał się jako kwartalnik. Założycielem i pierwszym redaktorem tego czasopisma był w latach 1949-1964 abp Józef Gawlina. Po nim redakcję przejął do 1970 roku bp Władysław Rubin, następnie bp Szczepan Wesoły. Czasopismo przeznaczone głównie dla duchowieństwa pracującego wśród Polaków za granicą. Publikowane w nim były artykuły z teologii praktycznej, kaznodziejskiej, kazania lub szkice kazań tematycznie związane z okrasami liturgicznymi. Po Soborze Watykańskim II „Duszpasterz” drukował prace z zakresu liturgiki i katechetyki oraz dokumenty Stolicy Apostolskiej i Kościoła w Polsce. Pełni rolę łącznika wśród kapłanów pracujących w duszpasterstwie polskim poza krajem. M. KowalczyK, „Duszpasterz Polski za Granicą”, EK, t. IV, kol. 398.

13 S. BudyŃ, Śp. Ks. abp Szczepan Wesoły 1926-20018, „Nasze Słowo”. Miesięcznik Polskiej Misji Katolickiej w Niemczech 2018, nr 10(516), s. 2; S. ŁoPATKO, M. SzCZERBIŃsKI, Ksiadz arcybiskup Szczepan Wesoly - opiekun polskiej emigracji, w: W nieustajacej trosce o polska diasporę, s. 23-46.

${ }^{14}$ Dekoracja orderem odbyła się w Ambasadzie RP przy Stolicy Apostolskiej w Rzymie, której w imieniu prezydenta RP dokonał sekretarz Stanu w Kancelarii Prezydenta Rzeczypospolitej Polskiej minister Adam Kwiatkowski.

${ }^{15}$ Dekoracja orderem odbyła się 11 grudnia 2008 roku w Ambasadzie RP przy Stolicy Apostolskiej w Rzymie.

${ }^{16}$ Lux ex Silesia - nagroda ufundowana w 1994 roku rzez metropolitę katowickiego abpa Damiana Zimonia. Przyznawana jest corocznie dla tych, którzy w swej działalności naukowej lub artystycznej ukazują wysokie wartości moralne i wnoszą trwały wkład w kulturę Górnego Śląska. Nazwa nagrody nawiązuje do dominikanów: św. Jacka i bł. Czesława Odrowążów, o których mówiono w Krakowie Ex Silesia Lux - Światło ze Śląska. Nagroda wręczana jest z okazji rozpoczęcia roku akademickiego w katowickiej katedrze. R. Dzwonkowski, Laudacja na cześć księdza Arcybiskupa Szczepana Wesotego, laureata nagrody „Lux et Silesia” wręczonej z okazji międzyuczelnianej inauguracji roku akademickiego 2007/2008, podczas mszy św. w Katedrze Katowickiej, 9 października 2007, „Śląskie Studia Historyczno-Teologiczne” 2008, t. 41, s. 5-9. 
oraz medal Fides et Ratio ${ }^{17}$. W 2012 roku został odznaczony Odznaką Honorową Bene Merito $^{18}$.

Jako znawca polskiej problematyki emigracyjnej, sytuacji ugrupowań polonijnych w świecie oraz ich organizacji, niezmordowanie wizytował polskie ośrodki duszpasterskie rozsiane na kontynentach świata. Z powodu tej posługi biskupiej więcej czasu w niektórych okresach spędzał poza Wiecznym Miastem. Słusznie więc nazywany był „biskupem na walizkach”. Także po przejściu na emeryturę, jak tylko pozwalały siły i zdrowie, służył Polakom rozsianym po świecie jako ich pasterz, nauczyciel i przyjaciel ${ }^{19}$.

W czasie posługi biskupiej wiele troski poświęcał młodzieży. Czynił to m.in. poprzez organizowanie przez ponad 25 lat kursów młodzieżowych w Loreto - były to wakacyjne spotkania dla polskiej młodzieży emigracyjnej z Europy. W czasie ich trwania umacniał młodych w wartościach chrześcijańskich rodziny, uwrażliwiał na ducha odpowiedzialności za polskie wartości kulturowe, zachowanie ojczystego języka, tożsamości religijnej, szkolnictwa polskiego oraz ducha wspólnotowości polskiej. Umacniał słowem i sakramentami świętymi - przede wszystkim sakramentem Ducha Świętego ${ }^{20}$. Dodawał ludziom ducha, by nie tracili nadziei, gdyż ostatecznie Bóg zwycięża. We wszelkiego rodzaju przemówieniach, listach i kazaniach kierowanych do rodaków podkreślał wartość polskiej kultury, tradycji i patriotyzmu w życiu emigracji. Uwrażliwiał swoich słuchaczy na ważność zachowania języka i tożsamości religijnej, motywował do organizowania i prowadzenia polskiego szkolnictwa na emigracji oraz polskich organizacji młodzieżowych i kombatanckich ${ }^{21}$.

Był czynnie zaangażowany w pomoc ludziom „Solidarności”. Dzięki jego zaangażowaniu Polonia wydatnie pomagała internowanym w stanie wojennym Polakom i Polkom oraz ich rodzinom. Wydatnie wspierał ks. Franciszka Blachnickiego ${ }^{22}$, którego stan wojenny zastał na Zachodzie.

17 Projekt utworzenia przy Kapitule Kolegiackiej na Bielanach Uniwersyteckiego Towarzystwa Fides et Ratio wyszedł od kard. Józefa Glempa, prymasa Polski i Wielkiego Kanclerza Uniwersytetu Kardynała Stefana Wyszyńskiego w listopadzie 2004 roku. Łączy ono osoby ze świata nauki z praktyką kontemplacji.

18 Odznaka Honorowa Bene Merito (Dobrze Zasłużonemu) - polskie resortowe odznaczenie cywilne nadawane przez Ministra Spraw Zagranicznych od 2009 roku, jako zaszczytne honorowe wyróżnienie przyznawane obywatelom polskim oraz obywatelom obcych państw za działalność wzmacniającą pozycję Polski na arenie międzynarodowej. Odznaka może być nadana tej samej osobie tylko raz i jest jednostopniowa.

19 Zmart abp Szczepan Wesoty, List abpa Wiktora Skworca, Katowice, 28 sierpnia 2018 roku.

20 A. Paluchowski, Dokumentalista Ducha Świętego, w: W nieustającej trosce o polska diaspore, s. 61-64.

${ }^{21}$ M. WŁosińsKI, Wartości religii w służbie zachowania przyszłości, w: tamże, s. 217-227.

22 Ks. Franciszek BlachNicKi (1921-1987) - polski kapłan, założyciel Ruchu Światło-Życie, więzień obozów koncentracyjnych, prześladowany przez Służbę Bezpieczeństwa PRL. Święcenia kapłańskie przyjął w 1950 roku w Katowicach. W 1954 roku zapoczątkował rekolekcje Oazy Dzieci Bożych metodą rekolekcji zamkniętych. W 1957 roku zorganizował i prowadził społeczną inicjatywę przeciwalkoholową - Krucjatę Wstrzemięźliwości. Władze komunistyczne obawiając się tej akcji, w sierpniu 1960 roku zlikwidowały tę inicjatywę, co ks. Blachnicki uznał za prześladowanie Kościoła i przejaw represji wobec narodu, za co został skazany na 13 miesięcy więzienia w zawieszeniu na 3 lata. Od roku 1963 roku zaczął działać tzw. ruch oazowy, który potem rozwinął się jako 
W ramach prac Konferencji Episkopatu Polski arcybiskup Szczepan Wesoły był sekretarzem Komisji ds. Duszpasterstwa Emigracyjnego, członkiem Komisji Maryjnej oraz Komisji ds. Środków Społecznego Przekazu. Należał do Papieskiej Rady ds. Duszpasterstwa Migrantów i Podróżnych.

Na co dzień odbierany był jako gorliwy kapłan i bezpośredni w obejściu biskup oraz patriota. Do końca pozostawał ,ubogi w duchu” i ubogi materialnie. Modlił się o poranku w polskim kościele św. Stanisława. Tu mieszkał ponad 50 lat. W tej świątyni odbyło się 30 sierpnia 2018 roku pożegnalne nabożeństwo żałobne za Zmarłego. Dnia 10 września tego roku w katedrze katowickiej zostało odprawione Requiem, po czym jego doczesne szczątki spoczęły w krypcie biskupów katowickich, w kościele świętych Piotra i Pawła w Katowicach ${ }^{23}$.

W homilii pogrzebowej Arcybiskupa metropolita katowicki arcybiskup Wiktor Skworc w słowach szczerych i zapadających w serca uczestników liturgii opisał osobę i posługę Zmarłego: „Zmarły pasterz, ciągle w drodze, ziemi miał tyle, ile pokrywała ją jego stopa, ale przez swoją posługę w tylu miejscach Ziemi rysował zarys owej ziemi jutra, nowej, pochodzącej od Boga, przemienionej w wieczność. W godzinie swej śmierci abp Szczepan zwinął swój namiot, zakończył życie nomada z pastorałem, wkroczył w nową rzeczywistość, w nowy świat, który - ufamy - jest już jego ziemią obiecaną, ojczyzną i domem"24.

Ruch Światło-Życie. Była to metoda 15-dniowych rekolekcji dla różnych grup młodzieży, dorosłych i rodzin. Po ogłoszeniu stanu wojennego w kraju poszukiwany był listem gończym, a śledztwo z tego okresu formalnie zakończono dopiero w roku 1992 roku. Od 1982 roku zamieszkał w ośrodku polskim Marianum w zachodnioniemieckim Carlsbergu. Powstało wtedy Międzynarodowe Centrum Ewangelizacji Światło-Życie, którego był animatorem. W czerwcu 1982 roku założył Chrześcijańską Służbę Wyzwolenia Narodów - dla narodów Europy Wschodniej. Śledztwo prowadzone przez IPN wykazało, że ks. Franciszek był inwigilowany przez Służbę Bezpieczeństwa za pośrednictwem jego najbliższych współpracowników: małżeństwa Jolanty i Andrzeja Gontarczyków, którzy byli tajnymi współpracownikami, a ks. Blachnicki mógł umrzeć na skutek otrucia. Postanowieniem z 6 lipca 2006 roku prokurator w Katowicach umorzył śledztwo wobec braku dostatecznych dowodów przestępstwa. Postanowienie o umorzeniu śledztwa, ipn.gov.pl, 2006-07-06 [dostęp: 24.06.2017].

${ }^{23}$ S. Budyń, Śp. Ks. abp Szczepan Wesoty, s. 2.

${ }^{24}$ Cyt. za: Zmart abp Szczepan Wesoty, List abpa Wiktora Skworca, Katowice, 28 sierpnia 2018 roku. 